\title{
УДК 619:636.2:591.11
}

РАЦЬКИЙ М.I., кандидат ветеринарних наук, mratskiy@ukr.net Інститут біології тварин НААН, м. Львів

\section{ГЕМАТОЛОГІЧНИЙ ПРОФІЛЬ КОРІВ РІЗНОГО РІВНЯ ПРОДУКТИВНОСТІ ТА ЇХ ТЕЛЯТ, ЗА ДІЇ ЛІПОСОМАЛЬНОГО ПРЕПАРАТУ}

Проведені дослідження показали, що кількість еритрочитів, вміст гемоглобіну і величина гематокриту у крові корів контрольних груп за 10 діб до передбачуваних родів $і$ на 5-ту добу після родів були меншими, ніж за 20 діб до отелення. Внутрішньом'язове введення тільним коровам за 20 діб до передбачуваних родів досліджуваного препарату спричиняло підвищення у крові кількості еритрочитів, вмісту гемоглобіну та величини гематокриту порівняно до тварин контрольної групи. $У$ телят,одержаних від корів яким застосовували досліджуваний ліпосомальний препарат, констатовано підвищення кількості еритрочитів, вмісту гемоглобіну та величини гематокриту, ніж у телят контрольної групи.

Ключові слова: корови, телята, еритрочити, гемоглобін, гематокрит, вітаміни.

Вступ. Збереження здоров’я молодняку сільськогосподарських тварин у ранньому віці $є$ однією з найактуальніших проблем тваринництва України. Економічні втрати від захворювань та загибелі продуктивного поголів'я, особливо молодняку в Україні є значними. Це зумовлено зниженням гомеостазу корів у період тільності, що призводить до порушення ембріонального розвитку, зниження вітамінів, макро- і мікроелементів у молозиві та молоці $[1,2]$.

Корови в останній місяць тільності перебувають у стані імунодефіциту, пов'язаного 3 розвитком плода та підготовкою організму до синтезу молозива, у їх крові змінюється кількість еритроцитів і концентрація гемоглобіну. Характерними показниками інтенсивності кровотворення $є$ кількість еритроцитів у крові та насиченість їх гемоглобіном [3, 4]. Одним із способів вирішення проблеми збереження молодняку є використання нових препаратів у формі ліпосомальної емульсії, що містять біологічно активні речовини, які підвищують імунний статус та гематологічні показники тільних корів та новонароджених телят.

Мета роботи полягала у з'ясуванні впливу парентерально введення коровам в останній місяць тільності ліпосомального препарату, до складу якого входять вітаміни $\mathrm{A}, \mathrm{D}_{3}, \mathrm{E}$, лецитин, L-метіонін, L-аргінін, натрію селеніт на гематологічні показники корів та їх новонароджених телят.

Матеріали і методи досліджень. Дослідження проведено у господарстві ТОВ «Молочні ріки» Сокальського району Львівської області на чотирьох групах тільних сухостійних корів по 5 тварин у кожній та їх новонароджених телятах. Групи тварин формували за принципом аналогів в залежності від рівня продуктивності - перша контрольна та перша дослідна з надоєм за лактацію 5 000-5 500 кг, друга контрольна та друга дослідна 3 надоєм 6 500-7 000 кг. Коровам дослідних груп за 20 та 10 діб до передбачуваних родів внутрішньом'язово вводили ліпосомальний препарат у склад якого входять вітаміни $\mathrm{A}, \mathrm{D}_{3}, \mathrm{E}$, лецитин, L-метіонін, L-аргінін, натрію селеніт дозою 0,04 мл на кг маси тіла тварини, коровам контрольних груп ізотонічний розчин натрію хлориду дозою 10 мл на тварину. Раціон тварин був збалансований за основними поживними речовинами згідно існуючих норм 
Кров для досліджень брали з яремної вени у корів до ранішньої годівлі за 20 та 10 діб до передбачуваних родів та на 5 добу після отелення, а у народжених від них телят у 5 добовому віці. У стабілізованій гепарином крові визначали кількість еритроцитів, вміст гемоглобіну, величину гематокриту, а також вираховували індекси червоної крові [5].

Одержані цифрові дані опрацьовано статистично з викоританням програмного пакету Microsoft Excel для персональних комп'ютерів, за допомогою загальноприйнятих методів варіаційної статистики.

Результати досліджень та їх обговорення. 3 наведених у таблиці 1 даних бачимо, що у крові корів контрольної групи з рівнем продуктивності 5 000-5 500 кг із зростанням терміну гестації констатовано тенденцію до зменшення кількості еритроцитів і вмісту гемоглобіну, а корів із рівнем продуктивності 6 500-7 000 кг - лише величини гематокриту. При цьому введення ліпосомального препарату сприяло збільшенню, порівняно 3 контролем, кількості еритроцитів, вмісту гемоглобіну та величини гематокриту у крові корів дослідної групи 3 рівнем продуктивності 5 000-5 500 кг за 10 діб до отелення відповідно на 4,6, 6,7 та 8,1 \%, а на 5-ту добу після отелення - на 5,3, 4,0 і 8,3 \%.

Водночас у крові корів з рівнем продуктивності 6 500-7 000 кг, яким вводили препарат, кількість еритроцитів і концентрація гемоглобіну за 10 діб до отелення були більшою відповідно на 1,9 та 6,8 \%, ніж у контролі, а на 5-ту добу після отелення — на 5,4 та 4,8 \%. Кількість еритроцитів і вміст гемоглобіну у крові телят обох дослідних груп були на 4,9 і 5,6 та 1,5 і 4,5 \% більшим, ніж у контролі. Отримані дані свідчать про стимулювальний вплив досліджуваного препарату на киснево-транспортну функцію крові в організмі корів і телят [6].

Таблиия 1

Гематологічні показники у корів та їх телят $(\mathrm{M} \pm \mathbf{m}, \mathrm{n}=4)$

\begin{tabular}{|c|c|c|c|c|c|}
\hline \multirow{3}{*}{ Показники } & \multirow{3}{*}{$\begin{array}{c}\text { Групи } \\
\text { тварин }\end{array}$} & \multicolumn{3}{|c|}{ Періоди досліджень } & \multirow{3}{*}{$\begin{array}{l}\text { Телята 5-ти } \\
\text { добового віку }\end{array}$} \\
\hline & & \multicolumn{2}{|c|}{ до отелення } & \multirow{2}{*}{$\begin{array}{c}\text { після отелення } \\
5 \text { доба }\end{array}$} & \\
\hline & & 20 діб & 10 діб & & \\
\hline \multicolumn{6}{|c|}{ продуктивність 5 000-5 500} \\
\hline \multirow[t]{2}{*}{ Еритроцити, Т/л } & к & $5,97 \pm 0,23$ & $5,85 \pm 0,36$ & $5,70 \pm 0,43$ & $6,15 \pm 0,18$ \\
\hline & д & $6,00 \pm 0,29$ & $6,12 \pm 0,45$ & $6,00 \pm 0,20$ & $6,45 \pm 0,06$ \\
\hline \multirow[t]{2}{*}{ Гемоглобін, г/л } & к & $106,6 \pm 4,11$ & $104,7 \pm 3,90$ & $100,1 \pm 3,82$ & $100,1 \pm 2,82$ \\
\hline & д & $102,9 \pm 3,49$ & $111,7 \pm 2,54$ & $104,1 \pm 3,86$ & $105,7 \pm 4,78$ \\
\hline \multirow[t]{2}{*}{ Гематокрит, л/л } & к & $0,36 \pm 0,02$ & $0,37 \pm 0,02$ & $0,36 \pm 0,02$ & $0,38 \pm 0,03$ \\
\hline & д & $0,39 \pm 0,02$ & $0,40 \pm 0,02$ & $0,39 \pm 0,02$ & $0,39 \pm 0,03$ \\
\hline \multicolumn{6}{|c|}{ продуктивність 6 500-7 000 } \\
\hline \multirow[t]{2}{*}{ Еритроцити, Т/л } & к & $6,20 \pm 0,29$ & $6,25 \pm 0,46$ & $6,07 \pm 0,40$ & $6,72 \pm 0,33$ \\
\hline & д & $6,17 \pm 0,23$ & $6,37 \pm 0,37$ & $6,40 \pm 0,06$ & $6,82 \pm 0,20$ \\
\hline \multirow[t]{2}{*}{ Гемоглобін, г/л } & К & $107,6 \pm 3,70$ & $107,3 \pm 3,47$ & $102,9 \pm 3,87$ & $104,3 \pm 4,60$ \\
\hline & д & $110,2 \pm 4,11$ & $114,8 \pm 2,05$ & $107,8 \pm 3,89$ & $109,0 \pm 1,45$ \\
\hline \multirow[t]{2}{*}{ Гематокрит, л/л } & к & $0,39 \pm 0,02$ & $0,38 \pm 0,02$ & $0,37 \pm 0,02$ & $0,37 \pm 0,03$ \\
\hline & д & $0,38 \pm 0,02$ & $0,38 \pm 0,02$ & $0,38 \pm 0,02$ & $0,38 \pm 0,03$ \\
\hline
\end{tabular}


Індекси червоної крові корів та їх телят $(M \pm m, n=4)$

\begin{tabular}{|c|c|c|c|c|c|}
\hline \multirow{3}{*}{ Показники } & \multirow{3}{*}{$\begin{array}{c}\text { Групи } \\
\text { тварин }\end{array}$} & \multicolumn{3}{|c|}{ Періоди досліджень } & \multirow{3}{*}{$\begin{array}{c}\text { телята 5-ти } \\
\text { добового віку }\end{array}$} \\
\hline & & \multicolumn{2}{|c|}{ до отелення } & \multirow{2}{*}{$\begin{array}{c}\text { після отелення } \\
5 \text { доба }\end{array}$} & \\
\hline & & 20 діб & 10 діб & & \\
\hline \multicolumn{6}{|c|}{ продуктивність 5 000-5 500 } \\
\hline \multirow{2}{*}{ COE, } & к & $60,5 \pm 4,06$ & $63,5 \pm 5,33$ & $64,1 \pm 5,54$ & $62,5 \pm 4,75$ \\
\hline & д & $66,6 \pm 5,33$ & $66,3 \pm 5,43$ & $65,8 \pm 4,38$ & $61,0 \pm 5,13$ \\
\hline \multirow{2}{*}{ ВГE, } & К & $17,8 \pm 0,06$ & $18,2 \pm 1,59$ & $17,8 \pm 1,28$ & $16,3 \pm 0,79$ \\
\hline & д & $17,4 \pm 1,24$ & $18,6 \pm 1,51$ & $17,5 \pm 1,22$ & $16,4 \pm 0,75$ \\
\hline \multirow{2}{*}{ СКГЕ, } & К & $29,8 \pm 1,80$ & $28,8 \pm 2,15$ & $28,1 \pm 2,32$ & $26,8 \pm 2,43$ \\
\hline & д & $26,1 \pm 0,57$ & $28,1 \pm 1,25$ & $26,6 \pm 1,10$ & $27,6 \pm 2,89$ \\
\hline \multirow{2}{*}{ КП } & K & $0,97 \pm 0,002$ & $0,99 \pm 0,09$ & $0,97 \pm 0,07$ & $0,92 \pm 0,04$ \\
\hline & д & $0,95 \pm 0,07$ & $1,01 \pm 0,08$ & $0,96 \pm 0,07$ & $0,92 \pm 0,04$ \\
\hline \multicolumn{6}{|c|}{ продуктивність 6 500-7 000} \\
\hline \multirow{2}{*}{ COE, } & к & $63,5 \pm 4,83$ & $62,4 \pm 4,86$ & $62,9 \pm 6,79$ & $56,3 \pm 5,26$ \\
\hline & д & $61,7 \pm 3,17$ & $60,7 \pm 2,25$ & $60,1 \pm 2,31$ & $56,3 \pm 3,22$ \\
\hline \multirow{2}{*}{ ВГE, } & $\kappa$ & $17,4 \pm 0,54$ & $17,4 \pm 1,21$ & $17,2 \pm 1,59$ & $15,6 \pm 0,94$ \\
\hline & д & $17,8 \pm 0,06$ & $18,2 \pm 1,21$ & $16,8 \pm 0,71$ & $16,0 \pm 0,46$ \\
\hline \multirow{2}{*}{ СКГЕ, } & К & $27,7 \pm 1,63$ & $28,1 \pm 2,19$ & $27,7 \pm 1,63$ & $28,4 \pm 2,91$ \\
\hline & д & $27,6 \pm 1,62$ & $30,0 \pm 1,56$ & $29,2 \pm 1,70$ & $28,8 \pm 2,54$ \\
\hline \multirow{2}{*}{ КП } & к & $0,94 \pm 0,03$ & $0,95 \pm 0,07$ & $0,94 \pm 0,09$ & $0,88 \pm 0,05$ \\
\hline & д & $0,97 \pm 0,002$ & $0,99 \pm 0,06$ & $0,92 \pm 0,04$ & $0,90 \pm 0,02$ \\
\hline
\end{tabular}

У клінічній практиці для оцінки співвідношення еритроцитів i насичення їх гемоглобіном прийнято визначати індекси червоної крові [5]. 3 наведених у таблиці 2 даних видно, що середній об'єм еритроцитів (COE) у крові корів контрольної групи з рівнем продуктивності 5 000-5 500 кг за 10 діб до отелення та на 5-ту добу після отелення, порівняно 3 попереднім періодом досліджень, збільшувався, а середня концентрацію гемоглобіну в еритроцитах (СКГЕ) - зменшувалась, що вказує на інтенсивне використання кисню в організмі корів у останній місяць тільності на ріст і розвиток плода. Введення коровам дослідних груп вітамінів A, $\mathrm{D}_{3}$, E, лецитину, L-метіоніну, L-аргініну, натрію селеніту у складі препарату, спричинило тенденцію до збільшення COE за 10 діб до та на 5-ту добу після отелення. порівняно з контролем.

Аналогічно зі змінами індексів червоної крові у тварин із продуктивністю $5000-5500$, зафіксовано зменшення СОЕ за 10 діб до отелення та на 5-ту добу після отелення в крові корів контрольної групи з рівнем продуктивності 6 500-7 000 кг. Введення коровам дослідних груп ліпосомального препарату спричиняло збільшення СКГЕ і зменшення СОЕ в крові за 10 діб до та на 5-ту добу після отелення, що свідчить про стимулювальний вплив досліджуваного препарату на киснево-транспортну функцію крові в організмі [7]. Про це також вказує тенденція до збільшення наповнення еритроцитів гемоглобіном та величина колірного показника у крові народжених від них телят.

Отже, отримані дані свідчать про стимулювальний вплив вітамінів $\mathrm{A}, \mathrm{D}_{3}, \mathrm{E}$, лецитину, L-метіоніну, L-аргініну, натрію селеніту у формі ліпосомальної емульсії на кисневотранспортну функцію крові в організмі корів і в народжених від них телят. 


\section{Висновки та перспективи подальших досліджень}

1. Введення коровам за 20 і 10 діб до передбачуваних родів вітамінів $\mathrm{A}, \mathrm{D}_{3}, \mathrm{E}$, лецитину, L-метіоніну, L-аргініну, натрію селеніту у формі ліпосомальної емульсії призводить до підвищення у периферичній крові корів кількості еритроцитів, вмісту гемоглобіну та величини гематокриту.

2. У крові телят, одержаних від корів яким вводили вітаміни $\mathrm{A}, \mathrm{D}_{3}, \mathrm{E}$, лецитин, Lметіонін, L-аргінін, натрію селеніт у формі ліпосомальної емульсії, кількість еритроцитів, вміст гемоглобіну, величина гематокриту та індекси червоної крові були вищими у порівнянні з тваринами контрольних груп.

\section{СПИСОК ЛІТЕРАТУРИ}

1. Memendez A. Defensis in the immunology of bacterial infections / A. Memendez, B.B. Finlay // Curr. Opin. Immunol. - 2007. - V. 19. - P. 385-392.

2. Hammon H. M. Free amino adds in plasmaof neonatal calvesare influence by feeding colostrurn for different durations or by feeding only milk replaccr / H. M. Hammon, J. W. Blum // J. Anirn. Physiol. and Anim. Nutr. - 1999. - 82.

3. Мазуркевич А. Й. Фізіологія тварин: підручник / А. Й. Мазуркевич, Карповський В. І., Камбур М. Д. та ін. - Вінниця: Нова Книга, 2008 - 424 с.

4. Влізло В. В. Фізіолого-біохімічні основи високої продуктивності великої рогатої худоби / В. В. Влізло, В. Г. Янович, І. Б. Ратич // Вісник аграрної науки. - 2010. - № 9. - С. 11-14.

5. Влізло В. В. Лабораторні методи досліджень у біології тваринництві та ветеринарній медицині: довідник / В. В. Влізло, Р. С. Федорук, І. Б. Ратич та ін.; За ред. В.В. Влізла. - Львів: СПОЛОМ, 2012. -764 c.

6. Влізло В. В. Жиророзчинні вітаміни у ветеринарній медицині та тваринництві: монографія / Влізло В. В., Куртяк Б. М., Вудмаска І. В. та ін.. - Львів, 2015. - 436 с.

7. L-arginine depletion in preeclampsia orients nitric oxide synthase toward oxidant species / Noris M., Todeschini M., Cassis P. et al. // J. Hypertension. - 2004. - Vol. 43, No. 3. - P. 614-622.

\section{ГЕМАТОЛОГИЧЕСКИЙ ПРОФИЛЬ КОРОВ С РАЗНЫМ УРОВНЕМ ПРОДУКТИВНОСТИ И ИХ ТЕЛЯТ, ЗА ДЕЙСТВИЯ ЛІПОСОМАЛЬНОГО ПРЕПАРАТА / РАЦЬКИЙ М. И.}

Проведенные исследования показали, что количество эритрочитов, содержимое гемоглобина и величина гематокрита, в крови коров контрольных групп за 10 суток до предсказуемых родов и на 5 ту сутки после родов были меньше, чем за 20 суток до отела. Внутримышечное введение стельным коровам за 20 суток до предсказуемых родов исследуемого препарата влекло повыпение в крови количества эритроцитов, содержимого гемоглобина и величины гематокрита, сравнительно $c$ животными контрольной группы. У теленков, полученных от коров которым применяли исследуемый липосомальный препарат, констатировано повыщение количества эритроцитов, содержимого гемоглобина и величины гематокрита, чем у теленков контрольной группы.

Ключевые слова: коровы, тельонки, еритроциты, гемоглобин, гематокрит, витамины.

\section{HAEMATOLOGICAL PROFILE OF COWS WITH DIFFERENT PERFORMANCE LEVEL AND THEIR CALVES UNDER ADMINISTRATION OF LIPOSOMAL DRUG / RATSKIY M.}

Introduction. In the article information about influence of liposomal drug with vitamins $A, D_{3}, E$, lecithin, L-methionine, L-arginin, sodium selenite administrated parenterally to the cows with different level of 
the productivity during the last month on the morphological indices in blood of cows and calves calving from them are presented. During the last month cows are in the state of immuno deficiency related to development of foetus and preparation of organism to the synthesis of colostrums. The amount of erythrocytes and concentration of hemoglobin change at that period.

The goal of the work. Was to ascertain the effect of parenteral administration of cows in the last month on the integrity of the liposomal preparation, which includes vitamins $A, D_{3}, E$, lecithin, L-methionine, L-arginine, sodium selenite on the hematological parameters of cows and their newborn calves.

Materials and methods. Blood for research was taken from the jugular vein from cows to the early feeding for 20 and 10 days before the expected births and for 5 days after calving, and from calves born at them at 5 day old age. In blood stabilized heparin, the number of erythrocytes, hemoglobin, hematocrit, and red blood cell indices were determined.

Results of research and discussion. The conducted researches have established that in blood of cows of control groups, 10 days before the expected births and on the 5th day after calving, the number of erythrocytes, hemoglobin content and the hematocrit were lower than 20 days prior to calving. Intramuscular administration of the drug to cows for 20 days to the intended births contributes to an increase in the number of erythrocytes, hemoglobin content and hematocrit values in comparison with the control animals. The introduction of vitamins $A, D_{3}$, E, lecithin, L-methionine, L-arginine, and sodium selenite into cows compared with control caused a tendency to increase the MCV for 10 days before and after calving of the 5th day. In newborn calves we note the increase in the number of erythrocytes, hemoglobin and hematocrit values, than in comparison to control group calves. Introduction to cows of the liposomal drug caused a tendency to increase the filling of erythrocytes with hemoglobin and color index and decrease in the blood of calves born from them.

Conclusions and prospects for further research. Introduction of cows for 20 and 10 days to the supposed genera of vitamins $A, D_{3}$, E, lecithin, L-methionine, L-arginine, sodium selenite in the form of a liposomal drug leads to an increase in the number of erythrocytes in the peripheral blood of the cows, the hemoglobin content and the size of the hematocrit. In the blood of calves derived from cows which were administered vitamins $A, D_{3}$, E, lecithin, L-methionine, L-arginine, sodium selenite in the form of a liposomal drug, the number of erythrocytes, hemoglobin, hematocrit and red blood indices were higher compared to animals of control groups.

Keywords: cows, calves, erythrocytes, hemoglobin, hematocrit, blood, lecithin, L-methionine, Larginine, vitamins.

\section{REFERENCES}

1. Memendez A. \& Finlay B. (2007) Defensis in the immunology of bacterial infections. Curr. Opin. Immunol. 19, 385-392 [in English].

2. Hammon H. M. \& Blum J. W. (1999) Free amino adds in plasmaof neonatal calvesare influence by feeding colostrurn for different durations or by feeding only milk replaccr. J. Anirn. Physiol. and Anim. Nutr. 82 [in English]..

3. Mazurkevych A. J., Karpovs'kyj V. I., Kambur M. D. ta in. (2008). Fiziologija tvaryn [Animal physiology]. Vinnycja: Nova Knyga [in Ukrainian].

4. Vlizlo V. V., Janovych V. G.,. Ratych I. B. (2010). Fiziologo-biohimichni osnovy vysokoi' produktyvnosti velykoi' rogatoi' hudoby [Physiological and biochemical bases of high productivity of cattle]. Visnyk agrarnoi' nauky. 9. 11-14 [in Ukrainian].

5. Vlizlo V. V., Fedoruk R. S., Ratych I. B. ta in. (2012). Laboratorni metody doslidzhen' u biologii' tvarynnyctvi ta veterynarnij medycyni [Laboratory methods of research in biology of livestock and veterinary medicine]. L'viv: SPOLOM [in Ukrainian].

6. Vlizlo V. V., Kurtjak B. M., Vudmaska I. V. ta in. (2015). Zhyrorozchynni vitaminy u veterynarnij medycyni ta tvarynnyctvi [Fat-soluble vitamins in veterinary medicine and livestock breeding]. L'viv [in Ukrainian].

7. Noris M., Todeschini M., Cassis P. et al. (2004) L-arginine depletion in preeclampsia orients nitric oxide synthase toward oxidant species. J. Hypertension. Vol. 43, 3., P. 614-622 [in English]. 